\title{
DOES ETHNIC AFFILIATION AFFECT THE CHOICE TO BE SELF-EMPLOYED? CASE STUDY ON THE LABOR MARKET IN ISRAEL
}

\author{
lyad Snunu*, Nicoleta Sîrghi \\ Doctoral School of Economics, Faculty of Economics and Business Administration, West \\ University of Timisoara, Timișoara, Romania \\ eyadsnunu@gmail.com \\ nicoleta.sirghi@e-uvt.ro
}

\begin{abstract}
The aim of the paper is to empirically examine the variables that influence the choice of economic status, with emphasis on the differences between Arabs and Jews in Israel regarding this economic choice. Self-employed workers - business owners or entrepreneurs - are the force that contributes to the progress of individuals, companies and countries and are, therefore, an important factor for economic policy makers. The sector of self-employed workers - despite the numbers above - is a tier of significant specific attention in the workforce. However, so far, the self-employed sector has not received the proper attention in the literatur. The results indicate differences in the economies in which Jews and Arabs work as self-employed workers, and it is evident that there are areas that are more typical of self-employed Jews or self-employed. The industries in which the self-employment rate is advantageous or equitable for the self-employed are vehicles (sales and repair), electricity and water supply, banking and insurance. The first two areas do not require higher education, and can be associated with neighborhood / home services that characterize the self-employed in this level of education. In contrast, in education, public administration and construction, Jews had a considerable advantage in the employment rate as self-employed.
\end{abstract}

Keywords: labor market, self-employed workers, economics of gender, supply and demand for labor

JEL classification: J15, J16, J21, J10, J11

\section{Introduction}

Over the years, research in Israel and the world has not explored the self-employed sector as part of the workforce in the economy in depth, and has not extensively and systematically discussed the self-related characteristics e.g., the common areas of self-employment, their income level, and gender, ethnics, national and behavioral aspects. These aspects might characterize self-employed versus paid employees or salaried-working in the economy. The lack of proper attention can be attributed to the relatively low numerical value of the self-employed in the various systems of the economy in most states' economies (Hamilton, 2000).

In Israel, looking at the last three population censuses conducted there raises the following picture; the proportion of self-employed in the workforce did not vary significantly between the three censuses. In 1983, the self-employment rate was 12.9\%, in 1995 the self-employment rate was $13.0 \%$, and in 2008 , the rate was $13.4 \%$. However, during these years the number of independent women increased from 20,000 in 1983 to about 93,000 in 2008. In addition, the proportion of self-employed women doubled from $15.7 \%$ to $29.4 \%$, and their weight among all women participating in the workforce increased from $5.5 \%$ to $8.5 \%$.

\footnotetext{
* Corresponding author: lyad Snunu
} 
From a macroeconomic perspective, it is noticeable that they have undergone far-reaching political-economic and societal changes, beginning with the 1977 political upheaval and the continuation of the economic stabilization emergency in July 1985, which marked the beginning of a de facto reduction of Israeli government involvement.

Changes in the economic outlook were manifested in a variety of aspects, such as a significant reduction in the flow of government investment and credit to the economy, developing and expanding employment opportunities, and providing greater space for the involvement of private parties in large parts of the economy, which was reflected, among other things, in increasing the number of public sector employees.

The structure of the paper is as follows: Section 2 presented the literature review; Section 3 presented the methodology; Section 4 presented the results of the regressions; and the conclusions and future research are given in Section 5.

\section{Literature review}

Based on prior works (e.g., Clark and Drinkwater, 2010; Blanchflower, 2004; Heim, 2015; Minola et al., 2016; Lombard 2001), and data available for the study, we examined twelve variables as have a probability of influencing the choice to be self-employed: nationality, gender, age, education, marital status, number of children, apartment ownership, occupation, industry, area of residence, country of birth and year of emigration to Israel.

Both the positive factors (Pull Factors) and the negative factors (Push Factors) are weighty motives that influence the decision of national, ethnic and religious groups and minorities to work as self-employed and business entrepreneurs (Clark and Drinkwater, 2010). The positive factors relate to the various personal resources held by the national, ethnic and religious group member, such as: culture, level of education, professional experience, etc. The negative factors are related to barriers to absorption and integration into the labor market and lack of job and employment opportunities.

These barriers stem from a policy of discrimination and deprivation, intentional or unintentional, on the part of the authorities at both the national and regional and local levels, the lack of proficiency in the majority, which is the dominant language in the state, and the lack of proficiency in dealing with various governmental, public and private bureaucracy mechanisms (Clark and Drinkwater, 2010; Waldinger and Aldrich, 1990) therefore, owning a business provides the minority with the opportunity for self-certification and career development in the quest for economic and social progress (Glazer and Moynihan, 1970) and success (McManus, 2001; Fairlie, 2007).

Discussion of the issue of self-employment among ethnic minorities reveals an inconclusive situation: Many studies in the literature have documented a tendency for minority people to choose self-employment as a way to get higher returns for their human capital (Portes and Jensen 1989; Waldinger et al. 1990; Le 1999; Clarck and Drinkwater 2000; Fairlie 2007). However, minority members may be in a state of lack of financial resources and social capital needed for self-employment (Aronson, 1991; Hout and Rosen, 2000; Robb and Fairlie, 2007), or in a situation where business owners suffer discrimination from lenders, suppliers, or customers (Coate and Tennyson, 1992; Blanchflower, 2004).

The flexibility of self-employment is very important to women, because despite all the changes and social and economic transformations, even in modern-day Israeli society (as in other Western European and North American societies, which are not characterized by traditionalism and conservatism as before), women still carry most of the burden of household management and raising children. Existing evidence suggests that flexibility is indeed a significant factor in women's choice to work as self-employed (Carr, 1996; Lim, 2015), but not among men seeking employment (Boden, 1999; Dawson et al., 2009), because women seek appropriate balance between continuing to perform family tasks 
(household management, childcare) without interruption, and finding a source of income over time, even though independent work is without job security.

Various sectors offer jobs that require the employee to have an appropriate and relevant professional academic education, thus blocking the education brings a person of low and medium education to work as an independent (Kangasharju and Pekkala, 2002). This offsets the correlation between education and independent work (see, for example, Luber et al. 2000; Boden, 1996; Lohmann and Luber, 2004; Arum and Müller, 2004).

Several studies have pointed to age as a factor that influences a person's decision to become independent. Regarding human capital and experience (often related to age), age is often found to be positively related to independent employment (Aronson, 1991; Parker, 2009).

Self-employment tends to be concentrated in sectors such as construction and services. Therefore, in economies where these sectors are relatively large, more self-sufficiency is expected (Aronson, 1991; Arum and Müller, 2004; Parker, 2009).

\section{Methodology}

This study addresses two research questions: Does ethnicity influence the choice of economic status in Israel? What are the characteristics of the self-employed among Israelis? Analysis of the variables will include reference to education and demographic characteristics among various ethnic groups in Israel. The research will be conducted in the Israeli economy, where the Jewish public is the majority and the Arab public is included in the minority group. Although the minority group in this study does not consist of immigrants, in many ways the situation of the Arabs in the State of Israel is like immigrants in European countries.

Based on the literature review above, we constructed 15 hypotheses as follows:

$H_{1}$ : along with the individual's personal characteristics (such as education and gender), there was a relationship between his affiliation with the ethnic (or religious or cultural) group and his choice to be independent and non-salaried

$\mathrm{H}_{2}$ : Women are less likely to be self-employed than men;

$\mathrm{H}_{3}$ : Education has a positive impact on the choice of independent employment;

$H_{4}$ : Experience and age are positively associated with independent employment;

$H_{5}$ : The rate of self-employment is higher among married;

$H_{6}$ : Large number of children may predict independent employment;

$H_{7}$ : Professional and skilled workers tend to be more independent than unskilled workers in both nationalities;

$H_{8}$ : Independent employment rate is higher in denser areas of Israel;

$H_{9}$ : Immigration (for Jews only) is positively related to independent employment;

$H_{10}$ : Owning an apartment (as a marker of individual wealth) increases the chances of being independent;

$H_{11}$ : There is an interaction between the economic branch and nationality in predicting independent employment;

$H_{12}$ : There is an interaction between education level and nationality in predicting independent employment;

$H_{13}$ : There is an interaction between marital status and nationality in predicting independent employment;

$H_{14}$ : There is an interaction between the number of births and nationality in predicting independent employment;

$H_{15}$ : There is an interaction between apartment ownership and nationality in predicting independent employment. 
The data in this work is taken from the 2008 State Census, as it provides the most comprehensive and reliable picture of the population at the "determining point" (the time point referred to by the census). Contrary to studies that sample a small portion of the population, census data is collected on a representative sample that is $20 \%$ of the state's population, and therefore inferences based on census data will be more reliable and accurate.

The original data was grouped by CBS into categorical variables, and some of the categories were grouped for the present study. All absentees under 24 or over 70 , or absentees whose employment status is unknown, or kibbutz members - were omitted from the analysis. The Logit probability model was used in the study, where the probability that a specific individual would be independent is:

$$
\operatorname{Pr}\left(y_{i}=1 \mid x\right)=\operatorname{Pr}\left(y_{i}^{*}>0 \mid x_{i}\right)=\operatorname{Pr}\left(\varepsilon_{i} \leq x_{i} \beta \mid x_{i}\right)=F\left(x_{i} \beta\right)=\frac{\exp \left(x_{i} \beta\right)}{1+\exp \left(x_{i} \beta\right)}
$$

When a latent variable that is linearly related to the values of the following equation (1.2):

$$
y_{i}^{*}=x_{i} \beta+\varepsilon_{i}
$$

And the latent variable is related to the binary variable by the following equation (1.3.):

$$
y_{i}=\left\{\begin{array}{l}
1 \text { if } y_{i}^{*}>0 \\
0 \text { if } y_{i}^{*} \leq 0
\end{array}\right.
$$

When, the error has a standard logistic distribution $\varepsilon$ with zero expectation and variance $\pi / 3$. The explained variable receives a value of 1 if the person is independent and 0 if another, anyone who is independent in the original data, is considered independent for the purposes of the analyzes, whether or not they employ other employees. Employees receiving wages were considered salaried $X=\left(x_{1}, x_{2}, \ldots, x_{K}\right)$.To examine the effect of each variable on the employment status, a odds ratio $(\mathrm{OR})$ is used. This measure answers the question: "How much more likely in one group to be independent than in another." Chance in the definition above is the size: Odds $=\frac{\boldsymbol{p}}{\mathbf{1 - p}}$, Where $\mathrm{p}=$ probability of success in the binomial model.

A logistic regression model basically predicts the log-odds ratio with a dependent variable. Therefore, the estimates obtained for the OR are basically estimates of the odds of success (independent), when their dummy variable receives a value of 1 , against the reference group. The sample includes 272,823 employees (84.8\%) versus 48,833 self-employed (15.2\%). The proportion of Arabs who participated in the observation was $11.6 \%$, and the rest, $88.4 \%$, were Jewish. The proportion of self-employed among Arabs is $16.1 \%$ and $15.1 \%$ among Jews. $100 \%$ of the Arabs in the sample were natives of Israel, and among Jews the distribution of country of origin was: $68.7 \%$ born in Israel, $14.7 \%$ born in the former USSR, 3.3\% born in America and Oceania, 3.2\% born in Morocco, 3.1\% born in Asian countries, $2.6 \%$ born in Africa, $1.4 \%$ were born in Romania and $2.9 \%$ were born in the remaining European countries. Among Jews, immigrant rates were as follows: $5.4 \%$ immigrated in 1960 or before, $4.9 \%$ in $1961-1971,3 \%$ in $1972-1979,2.8 \%$ in $1980-1989$, $6.6 \%$ in 1990-1991, 8.6\% after 1992 and the rest were born in Israel.

Table 1 shows that among Jews, the distribution between men and women is equal (about $50 \%$ each gender), among Arabs, about three-quarters of the sample are men and about a quarter are women. In addition, among the Arabs, the young groups (25-49) constitute the bulk, $86.6 \%$, while the above groups constitute only $68.3 \%$ among the Jews, while the older groups (65-69) constitute $31.7 \%$ compared to only $13.4 \%$ among the Arabs. One can see that the Arabs have a significant underrepresentation in the "other" family situation (including divorced, divorced and widowed), 2.3\% among Arabs versus 9.8\% among Jews, and at lower levels of education (primary and secondary) Arabs reach $65.8 \%$ versus $45.3 \%$ among 
Jews. Only, and as the academic ladder rises, the gap is reversed for the benefit of the Jews. Most of the Jews (48.5\%) are in the Central and Tel Aviv area, while most of the Arabs (52.3\%) are in the north, $17.8 \%$ are in Jerusalem and $16.4 \%$ in Haifa. In the rest of the country (ie in the south, central, Tel Aviv and Judea and Samaria), Arabs are at a very low percentage: $5.8 \%, 6.7 \%, 1 \%$ and $0 \%$ respectively. The occupation category found that $36.8 \%$ of Arabs work in industry and building, compared to only $13.1 \%$ among Jews, and while about $24.1 \%$ of Jews work as officials and administrators, only $9.9 \%$ of Arabs are employed in this category.

Table 1: Descriptive statistics

\begin{tabular}{|c|c|c|c|c|c|}
\hline Arabs & Jews & Occupation & Arabs & Jews & Gender \\
\hline $10.30 \%$ & $6 \%$ & $\begin{array}{l}\text { Non-professional } \\
\text { workers }\end{array}$ & $75.10 \%$ & $49.90 \%$ & Male \\
\hline $9.20 \%$ & $17.70 \%$ & $\begin{array}{l}\text { Academic } \\
\text { profession }\end{array}$ & $24.90 \%$ & $50.10 \%$ & Female \\
\hline $15.20 \%$ & $17.90 \%$ & $\begin{array}{l}\text { Free profession/ } \\
\text { technician }\end{array}$ & Arabs & Jews & Age \\
\hline $2.90 \%$ & $7.30 \%$ & Manager & $41.20 \%$ & $29.90 \%$ & $25-34$ \\
\hline $7 \%$ & $16.80 \%$ & Employee & $45.40 \%$ & $38.40 \%$ & $35-49$ \\
\hline $16.70 \%$ & $19.60 \%$ & Agent/salesman & $13.40 \%$ & $31.70 \%$ & $50-69$ \\
\hline $1.90 \%$ & $1.59 \%$ & $\begin{array}{l}\text { A skilled agricultural } \\
\text { worker }\end{array}$ & Arabs & Jews & Marital Status \\
\hline $36.80 \%$ & $13.10 \%$ & $\begin{array}{l}\text { Industry and } \\
\text { building }\end{array}$ & $13.30 \%$ & $14.80 \%$ & Single \\
\hline Arabs & Jews & Economic sector & $84.40 \%$ & $75.50 \%$ & Married \\
\hline $2.50 \%$ & $2.10 \%$ & Agriculture & $2.30 \%$ & $9.80 \%$ & Other \\
\hline $12.80 \%$ & $14.30 \%$ & Industry & Arabs & Jews & Educational level \\
\hline $0.40 \%$ & $0.80 \%$ & Electricity and water & $33.50 \%$ & $8.40 \%$ & Elementary school \\
\hline $15.40 \%$ & $3 \%$ & Construction & $32.30 \%$ & $36.90 \%$ & Secondary school \\
\hline $15 \%$ & $11.80 \%$ & Vehicle & $29.40 \%$ & $40.60 \%$ & BA degree \\
\hline $4.50 \%$ & $3 \%$ & $\begin{array}{l}\text { Hospitality and } \\
\text { restaurants }\end{array}$ & $4.10 \%$ & $12.50 \%$ & MA degree \\
\hline $8.30 \%$ & $6.70 \%$ & $\begin{array}{l}\text { Transportation and } \\
\text { communication }\end{array}$ & $0.70 \%$ & $1.60 \%$ & $\mathrm{PhD}$ \\
\hline $1.20 \%$ & $4.30 \%$ & $\begin{array}{l}\text { Banking and } \\
\text { insurance }\end{array}$ & Arabs & Jews & Area of living \\
\hline $7.40 \%$ & $15.30 \%$ & $\begin{array}{l}\text { Real Estate and } \\
\text { Rentals }\end{array}$ & $6.70 \%$ & $28.30 \%$ & Center \\
\hline $3.90 \%$ & $5.70 \%$ & $\begin{array}{l}\text { Public } \\
\text { administration }\end{array}$ & $17.80 \%$ & $8.70 \%$ & Jerusalem \\
\hline $16.50 \%$ & $14.80 \%$ & Education & $1 \%$ & $20.20 \%$ & Tel-Aviv \\
\hline $7.80 \%$ & $11.30 \%$ & Health and welfare & $16.40 \%$ & $10.90 \%$ & Haifa \\
\hline $3.30 \%$ & $5.50 \%$ & $\begin{array}{l}\text { Community and } \\
\text { service }\end{array}$ & $5.80 \%$ & $15 \%$ & South \\
\hline $0.70 \%$ & $1.20 \%$ & Household & $52.30 \%$ & $11.90 \%$ & North \\
\hline $0.20 \%$ & $0.10 \%$ & $\begin{array}{l}\text { Foreign } \\
\text { organizations }\end{array}$ & $0 \%$ & $4.90 \%$ & $\begin{array}{l}\text { Yehuda an } \\
\text { Shomron }\end{array}$ \\
\hline
\end{tabular}

Source: own processing

Table 2, which reflects the percentage of self-employed and the percentage of employees both among Arabs and among Jews in a cross-section of educational level, shows that 
among individuals without education and among individuals with a secondary education and among individuals with a graduate degree, there is a small gap between the percentage of Arab self-employed and the percentage of Jewish self-employed ( $17 \%$ and $18.8 \%$, respectively, among non-educated individuals, and $18 \%$ and $16 \%$, respectively, of those with a high school education, $13.1 \%$ and $14.2 \%$, respectively, of graduates). On the other hand, the gaps are widening when it comes to higher education, i.e. graduate and doctorate (PhD), so the percentage of Arab self-employed persons with a degree is $15.2 \%$ compared to $12.8 \%$ among Jews, and among PhDs, the gap is $5.9 \%(20.2 \%$ Of independent Arabs hold a doctorate, compared to $14.3 \%$ of independent Jews who have a Ph.D.

Table 2: Percentage of self-employed / salaried employees by education level

\begin{tabular}{|c|c|c|c|c|}
\hline & \multicolumn{2}{|l|}{ Arabs } & \multicolumn{2}{|l|}{ Jews } \\
\hline & $\begin{array}{l}\text { Salaried } \\
\text { employees [\%] }\end{array}$ & $\begin{array}{l}\text { Self-employed } \\
\text { [\%] }\end{array}$ & $\begin{array}{l}\text { Salaried } \\
\text { employees [\%] }\end{array}$ & $\begin{array}{l}\text { Self employed } \\
\text { [\%] }\end{array}$ \\
\hline Without education & 81.2 & 18.8 & 83 & 17 \\
\hline $\begin{array}{l}\text { Secondary-school } \\
\text { education }\end{array}$ & 84 & 16 & 82 & 18 \\
\hline Degree & 85.8 & 14.2 & 86.9 & 13.1 \\
\hline Qualified degree & 87.2 & 12.8 & 84.5 & 15.2 \\
\hline Ph.D. & 85.7 & 14.3 & 79.8 & 20.2 \\
\hline
\end{tabular}

Source: own processing

Table 3 below shows the distribution of the number of births (live births only) among Arab and Jewish women.

Table 3: Distribution of the number of births among Arab and Jewish working women

\begin{tabular}{|c|c|c|c|}
\hline General & Jewish women & Arab women & Number of births \\
\hline $18 \%$ & $17.5 \%$ & $24.7 \%$ & 0 \\
\hline $37.9 \%$ & $38.6 \%$ & $27 \%$ & $1-2$ \\
\hline $36.2 \%$ & $36.2 \%$ & $36.3 \%$ & $3-4$ \\
\hline $8 \%$ & $7.7 \%$ & $12 \%$ & +5 \\
\hline
\end{tabular}

Source: own processing

In general, the majority of Israeli families (74.1\%) include between one and four births, but when examining in-depth the number of births in the family and the differences between Arabs and Jews, we can find that the proportion of Arab families without births as a whole or between one and two births is lower among Arabs. (24.7\% and $27 \%$, respectively, compared with $17.5 \%$ and $38.6 \%$ among Jews). In the three to four births category we can see that the data are almost identical in both populations, but in the category of five births and above we can see that a gap has opened for the Arabs: $12 \%$ among the independent Arabs versus only $7.7 \%$ among the independent Jews.

\section{Results}

For a preliminary examination of the effect of nationality on self-employment, a simple logistic regression model was fitted with a single fee variable for Arab nationality, with the dependent variable being employment status (independent defined as "success" in the binomial model). Estimates of model parameters are presented in the table 4: 
Table 4: Parameter estimates in Model 1

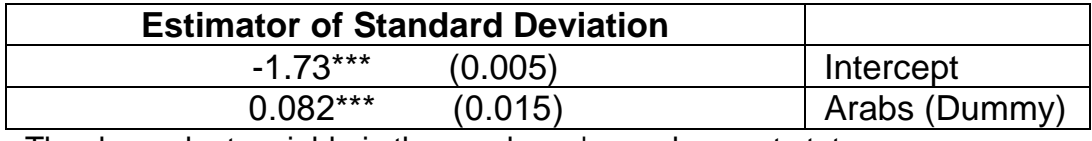

The dependent variable is the employee's employment status

(self-employed $=1$; else $=0$ )

Source: own processing

${ }^{*},{ }^{* *},{ }^{* * *}$ - significance at $5 \%, 1 \%, 0.1 \%$, respectively.

In Model 1, the Odds Ratio of Arab versus Jewish is $=1.085$, which means that the Arab's chance of being self-employed is 1.085 times (i.e. $8.5 \%$ greater) than the chances of a Jew being self-employed but, because there are differences in the distribution of salaried and self-employed. In order to extend Model 1, a multiple logistic regression model with dummy variables was adjusted for the different levels of the following demographic variables, in addition to nationality: gender, age, marital status, education, apartment ownership, area of residence and number of births, hereinafter referred to as Model 2.

In order to examine the effect of occupational and economic branch variables, three additional models were adapted- Model 3, which includes Model 2 in addition to the occupational variable; Model 4, which includes Model 2 in addition to the economic branch variable. To extend the knowledge of the occupational and economic branch variables and to examine the effect of migration variables and country of origin, another model was adapted: Model 5, which includes Model 2 and four other variables: economic branch, occupation, country of immigration and year of immigration. Model 4 show that the odds of an Arab relative to the Jew being cut by 5 percentage points $(\mathrm{OR}=\operatorname{EXP}(-0.051)=0.95028$ and thus the probability $=1-0.95028=0.4972 \approx 5 \%$ ).

The above findings can be understood with the help of the variation in the economic sectors between the Arabs and the Jews, and as mentioned, there are such differences and there are economic sectors that characterize the employment of Arab individuals and other economic sectors that characterize the employment of the Jewish individuals.

The coefficients of the sex variable $(1=$ male) in the four models are significant at $99 \%$ significance, and their Odds Ratio values are in the range of 1.6372 (Model 5) to 2.5702 (Model 2), that is, a man's chance of being relatively independent of a woman's, With the other variables being fixed, by about $64 \%$ by model 5 to about $157 \%$ by model 2 ).

The regression results show that the younger age groups (over 35 and under 49) and the older age groups (over 50 and under 69) had positive and significant coefficients at a significance level of $99 \%$, in all four models, so for ages 35-49, OR values Ranged from 1.8889 (in Model 2) to 2.0503 (in Model 5), meaning that belonging to this age group were more likely to be independent in the range of about $89 \%$ to about $105 \%$, and for ages $50-69$, values were in the range of $2.2864-2.6353$, which means that belonging to this age group is more likely to be independent in the range of about $129 \%$ to about $164 \%$.

Also, the regression results show that the married and separated and / or widows had positive and significant coefficients at the $99 \%$ significance level in all four models, so for the married OR values ranged from 1.3526 (model 2) to 1.5053 (model 5), so marriages are more likely to be independent in the range of about $35 \%$ to about $56 \%$, and for the individual and / or widowed values the values were in the range of 1.293 to 1.3485 , meaning that this population is more likely to be independent in the range of about $28 \%$ to about $39 \%$, and thus in fact accept that the chance of becoming independent increases as the age progresses.

The findings show that the estimates of the living areas were negative and significant at 99\% significance without exception. The above finding means that all individuals who do not live in the center of the country are less likely to be independent. 
Results shows that on the one hand, Arabs are more likely to be self-employed in some industries, mainly the industrial, electricity and water sectors, the automotive, transport and transport industries, and the banking and insurance industry, and on the other, construction, hospitality and restaurants, public administration, education, health and welfare, Foreign Households and Organizations - Jews are more likely to be independent than Arabs, with the largest gap in prospects observed in the foreign organizations. Also, in the real estate and rental sector, the chances of Arabs and Jews appear to be almost independent.

Therefore, it can be said that the effect of education on the chance of Arabs being independent is higher than the effect on the chance of Jews being independent, but among educated, the chance of Arabs of being independent is less than the chance of Jews. The proportion of self-employed among Arabs with secondary education, a graduate degree and a doctoral degree is greater than their proportion among Jews with similar education.

In the interaction between nationality and marital status, we received only $95 \%$ significant estimates in Model 8 for marriages and separated / divorced we got a 99\% significance level, with the family status estimates being significant at $99 \%$ significance level.

In the present study, the education variable had more levels, and it can be seen that the nationality variable moderates this relationship, and among educated Arabs the chance of becoming independent is higher compared to Jews of the same level of education. The limited presence of business corporations, government offices, and public companies in Arab localities may be conducive to pushing educated Arabs into independent employment. Under these restrictions, it can be stated that $H_{3}$ (the hypothesis examines whether education has a positive effect on the choice of independent employment) has been affirmed and education has a positive effect on the choice of independent employment (the effect of education on Jews is greater than its effect on Arabs).

The age group was a significant explanatory variable in all models, with the parameters in the large age group (50-69) tending to be larger than the middle age group parameters (3449). This finding is consistent with the longitudinal data provided by Svirsky and Ophir (2014), which indicate a positive relationship between age and employment rate, which increased between 1983 and 2008. That is, it can be determined that $H_{4}$ (the hypothesis tests whether experience and age are positively related to independent employment) has been confirmed and it can be determined that experience and age are positively associated with independent employment.

With regard to $H_{5}$ (which tests whether the rate of independent employment is higher among married people), the models predicted that married people were more likely to be independent, but models $6-11$, which included the interaction of nationality $\times$ marital status, predicted married Arabs were less likely to be independent than married Jews.

Regarding $\mathrm{H}_{6}$ (hypothesized that the number of births is positively associated with the likelihood of being self-employed), no definitive direction was found that affects the results in terms of both significance and direction of effect, and therefore the hypothesis cannot be corroborated. Indeed, in the study, we found support for the hypothesis that professional and skilled workers tend to be more independent than unskilled workers in both nationalities (as $H_{7}$ tests).

In the present study there is no consistent finding regarding the effect of the residential area, which means that the eighth hypothesis $H_{8}$ cannot be corroborated (a hypothesis examining whether the employment rate is higher in denser areas of Israel). It is found that in the center of the country the chance of being independent for Arabs and Jews is greater, but in the literature the largest rate of independence is actually in Tel Aviv. This bias may be due to differences in the residential distributions of both sectors, and these parameter estimates cannot be interpreted.

Regarding the ninth hypothesis test $H_{9}$ (which deals with Jewish immigration only and examines whether immigration is negatively related to independent employment), we find that, contrary to the findings of Leshem (2009), models that included immigration variables 
(country of origin, year of emigration) predicted less likely immigrants to self-employment. . This finding may be explained by the mediation of a generation variable in the country over the strength of the relationship between other variables and independent employment (for example, people born to families who are in more generations in the country are more likely to own land or real estate).

Contrary to (Banerjee and Newman, 1993) who argued that the degree of individual wealth affects choice to be independent, as wealthy people have easier access to the capital market, in the present study we found that owning a home (a marker of wealth) reduces the chance of the Israeli be independent, so $H_{10}$ can be rejected.

To examine the interaction between the economic branch and the nation, namely Hypothesis number $\left(H_{11}\right)$, we consider the odds in a model that describes the absolute chance of an Arab being independent versus the absolute chance of a Jew being independent and we find that Arabs are more likely to be self-employed in certain industries, mainly in manufacturing, electricity and water, automotive, transport and transport, and banking and insurance, and Jews are more likely to be self-employed than Arabs in industries: construction, hospitality and restaurant, public administration, education, health and welfare, Community and services, households and foreign organizations, and in the real estate and rental sector, the prospects of Arabs and Jews appear to be almost identical. Therefore, $\left(H_{11}\right)$ has been confirmed. For the education variable $\left(H_{12}\right)$, there was a significant interaction between the education and the nationality variable. However, on the other hand, some of the education variables themselves were not significant (a master's degree variable and a doctoral variable), so the results must be taken very carefully.

Also, and because there are significant differences between the common distributions of education variables and employment status in both sectors (for example, underrepresentation of Arabs in the Ph.D. group); it is difficult to interpret estimates of the education variable. Therefore, it can be argued that $H_{12}$ was confirmed. The interaction between nationality and marital status $\left(H_{13}\right)$, is significant for married status at $95 \%$ significance and for marital status and divorced and / or widowed at $99 \%$, with estimated variables married and divorced and / or widowed by themselves, the significance level is $99 \%$ significant. It appears that the influence of "married" marital status on the chance of being independent among Arabs is higher than the effect of "married" marital status on the prospect of being independent among Jews.

We compared the odds of being self-employed and not a salaried employee of the Arab individual who owns an apartment with the odds of the Jewish individual having an apartment, and the regression results are why we reject the hypothesis

we have almost equaled the odds of the Arab individual with the apartment and the Jewish individual with the apartment in the prospects of being independent and non-salaried, which is why we reject $\left(H_{15}\right)$.

\section{Conclusions}

In the present study, we have assumed that the extent to which an individual is influenced by his or her personal data (education, gender, race and ethnicity, etc.), the culture in which he grows, is related to variables that influence his or her decision and choice of employment status. And so, these characteristics pose a research challenge to many social policy scholars. The study was conducted in the Israeli economy, where the Arab public is the minority group and the Jewish public is the majority. In the study, we used the 2008 Census data, since the Census provides the most comprehensive and reliable picture of a particular population at the "determining point" (the time point to which the census refers). Contrary to studies that sample a small portion of the population, census data is collected on a representative sample that is $20 \%$ of the state's population, and therefore inferences based 
on census data will be more reliable and accurate. Census data is used by the Central Bureau of Statistics (CBS) in the official analyzes it conducts.

The results indicate differences in the economies in which Jews and Arabs work as self-employed workers, and it is evident that there are areas that are more typical of self-employed Jews or self-employed. The industries in which the self-employment rate is advantageous or equitable for the self-employed are vehicles (sales and repair), electricity and water supply, banking and insurance. It can be hypothesized that the first two areas do not require higher education, and can be associated with neighborhood / home services that characterize the self-employed in this level of education. In contrast, in education, public administration and construction, Jews had a considerable advantage in the employment rate as self-employed. There are four main limitations to the study: there was no distinction between self-employed with a small number of employees and self-employed with a large number of workers; in the present study, we did not consider intergenerational transition as a factor affecting choice to be independent; failure to address the spouse's employment status; excluding variables that may explain an individual's decision to be independent and not salaried to the models built.

\section{References}

Aronson, R. L., 1991. Self-employment: A labor market perspective. Ithaca, NY: ILR Press. Arum, R., and Müller, W., 2004. The Reemergence of Self-Employment: Comparative Findings and Empirical Propositions. The Reemergence of Self-Employment. A Comparative Study of Self-Employment Dynamics and Social Inequality. Princeton Oxford, pp. 426-454.

Banerjee, A. V., and Newman, A. F., 1993. Occupational choice and the process of development. Journal of Political Economy, 101 (2), pp. 274-298.

Blanchflower, D. G., 2004. Self-employment: More may not be better (No. w10286). National Bureau of Economic Research.

Boden Jr, R. J., 1996. Gender and self-employment selection: An empirical assessment. The Journal of Socio-Economics, 25 (6), pp. 671-682.

Boden Jr, R. J., 1999. Flexible working hours, family responsibilities, and female selfemployment: Gender differences in self-employment selection. American Journal of Economics and Sociology, 58 (1), pp. 71-83.

Carr, D., 1996. Two paths to self-employment? Women's and men's self-employment in the United States, 1980. Work and occupations, 23 (1), pp. 26-53.

Clark, K., and Drinkwater, S., 2010. Recent trends in minority ethnic entrepreneurship in Britain. International Small Business Journal, 28 (2), pp. 136-146.

Coate, S., and Tennyson, S., 1992. Labor market discrimination, imperfect information and self employment. Oxford Economic Papers, 44 (2), pp. 272-288.

Dawson, C., Henley, A., and Latreille, P., 2014. Individual motives for choosing self-employment in the UK: Does region matter? Regional Studies, 48 (5), pp. 804-822.

Fairlie, R. W., 2007. Entrepreneurship among disadvantaged groups: Women, minorities and the less educated. pp. 437-75 in Simon Parker (ed.), The Life Cycle of Entrepreneurial Ventures. International

Glazer, N., and Moynihan, D. P., 1970. Beyond the Melting Pot: The Negroes, Puerto Ricans, Jews, Italians, and Irish of New York City (Vol. 63). Cambridge, MA: MIT Press.

Hamilton, B. H., 2000. Does entrepreneurship pay? An empirical analysis of the returns to self-employment. Journal of Political Economy, 108 (3), pp. 604-631.

Heim, B. T., 2015. Understanding the decline in self-employment among individuals nearing retirement. Small Business Economics, 45 (3), pp. 561-580.

Hout, M., and H. Rosen., 2000. Self-employment, family background, and race. Journal of Human Resources 35 (4), pp. 670-92. 
Kangasharju, A., and Pekkala, S., 2002. The role of education in self-employment success in Finland. Growth and Change, 33 (2), pp. 216-237.

Leshem, A., 2009. Integration of Immigrants from the former Soviet Union, 1990-2005: Multidisciplinary Infrastructure Study. Jerusalem: Absorption Div., JDC Israel. [Hebrew].

Lim, K., 2015. Self-Employment, Workplace Flexibility, and Maternal Labor Supply: A Life-Cycle Model. Manuscript, University of Michigan.

Lombard, K. V., 2001. Female self-employment and demand for flexible, nonstandard work schedules. Economic Inquiry, 39 (2), pp. 214-237.

Lohmann, H., and Luber, S., 2004. Trends in self-employment in Germany: different types, different developments. The Reemergence of Self-Employment. A comparative study of self-employment dynamics and social inequality, pp. 36-74.

McManus, P. A., 2001. Women's participation in self-employment in western industrialized nations. International Journal of Sociology, 31 (2), pp. 70-97.

Minola, T., Criaco, G., and Obschonka, M., 2016. Age, culture, and self-employment motivation. Small Business Economics, 46 (2), pp. 187-213.

Parker, S. C., 2009. The economics of entrepreneurship. Cambridge University Press.

Portes, A., and Jensen, L., 1989. The enclave and the entrants: Patterns of ethnic enterprise in Miami before and after Mariel. American Sociological Review, 54, pp. 929-949.

Waldinger, R. D., Aldrich, H., and Ward, R., 1990. Ethnic entrepreneurs: Immigrant business in industrial societies (Vol. 1). Sage Publications, Inc.

Robb, A. M., and Fairlie, R. W., 2007. Access to financial capital among US businesses: The case of African American firms. The Annals of the American Academy of Political and Social Science, 613 (1), pp. 47-72.

\section{Bio-note}

lyad Snunu, is PhD Student, second year of study, Doctoral School of Economics at the Faculty of Economics and Business Administration, West University of Timişoara, Romania. The thesis title is: „Labour Market and Self - Employment. The Case of Israel.

Nicoleta Sirghi, is Professor PhD habil. of Economics at the Faculty of Economics and Business Administration, West University of Timisoara, Romania. The current research field is related to study the market structures with applications in economics. She reviewed articles submitted to ISI and BDI journals. She has published 9 books and over 90 articles in ISI and BDI journals. 